\title{
Introduction
}

\author{
Mora L. McLean
}

The West African youth presence in the American postindustrial port City of Newark, New Jersey, is significant, varied, and intricately woven into the social fabric, in both present-day and historic terms. The outwardly seamless integration of these young Black immigrants into Newark's residential, social, and commercial life belies the distinctive circumstances under which they have arrived, kinds and levels of resources upon which they can draw, and pathways available to them as they endeavor to thrive. For instance, in 2010 , under the headline "Held as slaves, now free," CNN reported the crackdown of a highly profitable child trafficking operation in the Newark Metropolitan Area. Some 20 girls, most in their early teens, from various West African countries, testified to being held captive by a Togolese couple, who tricked them into traveling to the United States on the promise of an education, then forced them to work 14- to 16-hour days in hair braiding salons, boasting a largely African American clientele (Bronstein, Lyon, \& Poolos, 2010; Salomon, 2010). Speaking before the thousands who attended Rutgers University-Newark's, 2018 commencement, the then undergraduate student body president reflected on the travails and triumphs of transitioning from her birthplace in Nigeria to life in New

M. L. McLean $(\bowtie)$

Rutgers University-Newark, Newark, NJ, USA

e-mail: m.mclean@rutgers.edu

(C) The Author(s) 2020

M. L. McLean (ed.), West African Youth Challenges and

Opportunity Pathways, Gender and Cultural Studies in Africa and the Diaspora, https://doi.org/10.1007/978-3-030-21092-2_1 
Jersey, and how the iconic image of Queen Latifah-the rapper, songwriter, actor, producer, and Newark native-inspired her to persevere. Offering words of encouragement to many in the audience, she pronounced: "To every black girl who has ever felt undeserving, underestimated, unworthy, this is for you!" (Rutgers University-Newark, 2018). In 2019, the New Jersey Historical Commission awarded support for the work of a young Ghanaian-born researcher who is using archived "fugitive slave" advertisements to document the enslavement of African people throughout the state of New Jersey in the period between 1783, the official end of the American Revolution, and 1808, when the US government officially banned American participation in the transatlantic slave trade (Amemasor, 2002). The seeds of his passion for probing this history took root after he earned his bachelor's degree from the University of Cape Coast, and took on a first job educating visitors to Ghana's Cape Coast Castle Museum-established at the infamous seventeenth-century fortress and slave trading post. After going on to earn a doctoral degree from Rutgers University-Newark, he shifted the focus of his passion for probing this history to the US side of the Atlantic.

In the spring of 2016, the Joseph C. Cornwall Center for Metropolitan Studies (Cornwall Center) at Rutgers University-Newark announced the results of research showing an exceptional increase in the African-born immigrant portion of the Newark's majority Black population. The findings confirmed that Newark's majority Black (48.7\%) and Hispanic (34.4\%) population is complexly diverse. Members include descendants of families who were part of the Great Migration-the twentieth-century exodus of millions of Black southerners seeking escape from the routinized humiliation and violence of Jim Crow segregation-and subsequent waves of new immigrant families from Brazil, the Caribbean, and the African continent, following the elimination of racially biased US immigration quotas in 1965. Today, West Africans-largely from Ghana, Nigeria, and Liberia-are among the fastest-growing segments of the city's immigrant population, arriving in numbers exceeding foreign-born residents from every other world region, except Central America.

The release of these findings came on the heels of Rutgers UniversityNewark's announcement of a comprehensive plan for realizing its commitments as an anchor institution, serving the needs of residents of the Greater Newark Area, New Jersey's largest-and second poorestmetropolis, just minutes west of New York City (Rutgers UniversityNewark, 2014). The plan, which remains in effect, accords high priority to 
community-university partnerships aimed at addressing acute, longstanding educational and other poverty-related challenges, stemming from decades of systematic exclusion, the decimation of manufacturing, chronic joblessness, and increasing income and wealth inequality.

Emerging from this context, this book collection offers a transatlantic, transnational exploration of barriers that undermine conditions of life for African and African-descendant youth, and limit their horizons. Beyond providing data and analysis, it also describes practical approaches to overcoming barriers and strengthening young people's ability to transition from youthhood to satisfying adult lives. Moreover, departing from the prevalent tendency to privilege US frameworks and perspectives, the dominant focus of this collection is on learning more about the African context in which increasing numbers of Newark youth spend significant portions of their young lives and, after emigrating, often maintain active family connections. In addition, by focusing on African youth, and mainly from African researcher and practitioner perspectives, the collection makes groundbreaking contributions to the field of youth studies.

\section{The Need for Comparative Research}

The methodological and theoretical challenges posed by any attempt to analyze conditions associated with youthhood, let alone devise ameliorative interventions, and transcontinentally, are formidable. But as scholar-activist Joschka Philipps (2014) argues, it is possible to surmount such challenges, and taking them on holds the potential to yield important breakthroughs in our understanding of "how different contexts, be they geographical, economic, political or professional, impact young people" (p. 1363). Philipps proffers an analytical and methodological approach to overcoming academic disciplinary silos that are part of the colonial legacy. He argues for transgressing the conventional divide in academia whereby "youth studies" and the "core disciplines," such as sociology, focus mainly on the so-called developed world, while the so-called developing world draws the attention of anthropology and area studies (Philipps, 2018, p. 2). Philipps (2018) makes the case for transforming youth studies so that it encompasses the majority of the world's youth. Drawing on the literature (e.g., Comaroff \& Comaroff, 2005), he argues that research on Africa - the world region with the largest concentration of youth, one-fifth of the world's youth population, and rapidly increasing (Yahya, 2017) - is a fruitful source of methodological and theoretical insights from which sociological and other studies of 
"global youth" stand to benefit. This collection is congruent with the premise that the field of youth studies (which largely ignores African youth) and the field of African Studies (which focuses on African youth, but mainly in ways that are self-referential) would be mutually enriched by more encompassing approaches to studying "youth" (Philipps, 2014).

Adopting a case-based, comparative analysis approach to investigating the range of attitudes, behaviors, and experiences of African youth and youth in the African diaspora in the United States makes sense for historical as well as heuristic reasons. It is no accident that, regardless of geographical context-and whether measured at the local, national, or global level-health, education, employment, and other indicators of well-being for Black youth are poor relative to White youth and, except in rare instances, youth in other ethnic and racialized categories. Nor is it coincidental that-whether analyzed from a youth studies or African studies perspective-scholarly investigations of youth-associated characteristics that are perceived to be threatening or dysfunctional (e.g., urban crime, violent protest, and irregular migration) focus disproportionately on young Black men (Philipps, 2018, pp. 6-7).

From the perspective of social and political philosophy, Charles Mills' (1997) analysis of the core centrality, and unstated assumptions, of white supremacy in structuring the modern world provides a useful framework for understanding the shared predicaments of African and African diaspora youth, and similarities in the ways in which they are viewed and characterized, in contrast to non-Black youth. He articulates the centuries-long process of "norming space" and "spacing individuals" by imprinting them with certain characteristics. The racialized identity and spaces with which contemporary Black youth (and other subaltern persons) are associated worldwide function together as a circular indictment: "You are what you are in part because you originate from a certain kind of space, and that space has those properties in part because it is inhabited by creatures like yourself" (Mills, 1997, p. 42). The circular indictment functions equally whether applied to the African continent in the global context or "inner cities" of the United States.

Observing a similar construct, historical analyses of the intellectual foundations of policy prescriptions for understanding the causes of US domestic and global poverty note a tendency to draw linkages between explanations of juvenile delinquency, criminology, and social unrest and understandings of poverty as ultimately a problem of individual or group failings, rather than imbedded structures. These patterns prevailed during 
the overlapping era of Cold War "development," and the US domestic War on Poverty, in the 1960s (Katz, 2013, pp. 10-12, 148-155; O'Connor, 2001, pp. 113-125) and have since reemerged. Regardless of particular explanations of cause and effect, whether they reside in the Global North or the Global South, young people who live in poverty and are Africanborn or of African descent are disproportionately burdened by the global phenomena of increasing income and structural inequality. Thwarted by systemic barriers and discrimination based on gender, ethnicity, race, and other forms of identity, they face daunting obstacles in meeting basic needs, accessing education, transitioning to meaningful and decent work, engaging in civic participation, improving their conditions of life, and achieving their full potential. As Alcinda Honwana (2014) observes, "waithood" best captures the reality that for many, if not most, of these youth, conventional paths to adulthood are perceived to be, and are in fact, out of reach.

The changing demographics of majority Black urban populations in the United States and the historical bases of structural inequality are among the factors spurring contemporary transatlantic Black youth movementsyet another potentially fruitful area for more transatlantic collaboration among researchers and practitioners and comparative research. For instance, the Black Lives Matter movement was initially sparked by the 2013 murder of Trayvon Martin, but has since purposefully transformed itself into a global network (Black Lives Matter, n.d.). Opal Tometi, one of the movement's cofounders, also previously led the New York-based Black Alliance for Just Immigration (BAJI), which advocates on behalf of Black immigrant communities from Africa, the Caribbean, and Latin America (BAJI, n.d.). She attributes much of her worldview and activism to her Nigerian immigrant family origins combined with her experience growing up Black and female in the United States. The Black Lives Matter movement's transnational commitment reflects a recognition of connected existential, socioeconomic, and political challenges that impact Black people, and especially Black youth, around the world, demanding strategies and solutions which extend beyond borders (BBC News Africa, 2018; Flanders, 2015; Tometi, 2015). Historian Barbara Ransby (2018) and sociologist Alondra Nelson (2016) situate the Black Lives Matter movement within a long lineage of transcontinental youth movements. Along these same lines, Krystal Strong (2018) observes:

A generation or more removed from the struggles that achieved political independence in African nations and the attainment of certain legal rights 
for Black people in the United States, Black youth across continental boundaries are calling into question deeply held ideas about intergenerational progress. (p. 276)

In her essay, provocatively titled "Do African Lives Matter to Black Lives Matter? Youth Uprisings and the Borders of Solidarity," Strong advocates in favor of "more meaningful engagement with contemporary scholarship and struggles in Africa and other global contexts, in the interest of research and solidarity practices that have as their aim the full valuation of Black lives everywhere" (p. 266).

More widespread and purposeful exploration of these connections would illuminate how and why the life experiences and challenges of Black youth in Africa and in the United States (as well as other parts of the world) are both similar and different, and how proposed interventions on either side of the Atlantic might be mutually informed and better conceived.

\section{"Youth" And "Development"}

Consistent with the social science literature, the collection as a whole treats youth as a constructed, contingent, and shifting category, dependent not merely upon biological age and psychological processes, but also shaped by specific historical, socioeconomic contexts and cultural understandings and meanings (Durham, 2000; Honwana \& De Boeck, 2005). Taken together, the chapters draw on multiple approaches to analyzing challenges and opportunities as youth navigate various life transitions. The life course framework - especially the movement into, through, and out of school-figures prominently, but the salience of youth agency and worldviews as well as social forces is also recognized (Hardgrove, Pells, Boyden, \& Dornan, 2014).

Collectively, the book contributors recognize that the material challenges to well-being among African youth are real. With roughly $40 \%$ of the population under age 15 and a youth population aged 15 to 24 estimated at 226 million (or $40 \%$ of the world's total), Africa has the world's fastest growing and youngest population. Western and Eastern Africa account for more than half of the continent's births and are projected to account for two-thirds by the end of the twenty-first century. For instance, by 2050 , one-fifth of children under 18 in Africa will live in Nigeria (United Nations International Children's Emergency Fund [UNICEF], 2014). With its 
expanding megacities, high proportion of youth, and insufficient educational resources and opportunities for gainful employment to meet demand, Nigeria epitomizes the Western Africa trajectory.

This collection acknowledges the significance of statistical evidence pointing to Africa's so-called youth bulge, but the "development imperative" is not a central or otherwise explicit concern of any of the chapter contributions in this book. Where educational access and attainment and employment are discussed in these chapters, the concern is with how these variables undermine or strengthen the capacity of marginalized youth to improve their material conditions and secure basic needs, to escape longterm poverty, and to achieve well-being. In the literature, poverty is firmly established as a variable associated with trauma, harmful stress, and a sense of hopelessness - the psychological and other burdens that can compromise the cognitive resources, mental health, and noncognitive skills human beings need to pursue a satisfying life.

The collection is organized into three parts, emphasizing the themes of (1) migration; (2) agency and aspirations; and (3) vulnerability and wellbeing, respectively. These three dimensions figure prominently in the lives of West African youth in and beyond the continent, shaping the obstacles they face and the pathways by which they seek to surmount them. The chapters clustered within each section foreground the theme under which they are organized in contrasting ways. But just as in lived experience, to varying degrees, the themes surface throughout the book.

\section{Migration}

Contrary to the news headlines emanating from mainstream European and US media, the volume of migration within West Africa and to other regions of the continent is at least ten times greater than toward European countries (Charrière \& Frésia, 2008). The pervasiveness of migration within and to West Africa is such that the number of immigrants residing in the region exceeds that of any other region of the continent.

Youth are at the forefront of spurring ongoing changes in the configurations of migration in and from West Africa. They are also the segment of the population most vulnerable to any associated negative consequences. In 2008, the United Nations High Commissioner for Refugees (UNHCR) observed that "West Africa ... has the distinguishing feature of many urban refugees, most of them citizens of ECOWAS [Economic Community 
of West African States] countries" (Charrière \& Frésia, 2008 p. 16), and that the majority are under 40 , including significant numbers of adolescents and children under 18. The UN agency further concluded:

The demographic explosion, urbanization and the economic slowdown have resulted in a growing individualization of life and family styles, redefining the place of young people, who now are handed the responsibility of making a living for their parents. Today more than ever the majority of young people see mobility as the best-if not the only option to secure their family's situation. (Charrière \& Frésia, 2008, p. 11)

West African youth classified as internal migrants (at times perceived as foreigners, even in their own country), or undocumented immigrants abroad, are in a situation where their safety and security is compromised (Mberu \& Pongou, 2010). They are among the world's most vulnerable "stateless" populations - excluded from enjoying the benefits of citizenship, including access to educational resources that are critical to improving their life chances.

The dynamic of internal youth migration in West Africa is the focus of Daniel Kyereko's chapter. His study of out-of-school migrants in Ghana makes a contribution to both research and practice focused on increasing access to education in Africa, and especially West Africa. It highlights the prevalence of south-south migration overall, and intra-West African migration in particular. The study goes beyond the conventional focus on sterile, quantitative data by providing qualitative analysis and insights into the thinking and motivations of migrant parents and children, as well as teachers and school personnel in Ghana, the host country. Kyereko's research reveals that, in contrast to findings of existing research focusing mainly on dropouts, migrant children in Ghana are, for varying reasons, more likely to never have enrolled in school in the first place. Among these reasons, migrants' distrust of the local school system looms large. The question of whether education is an efficacious poverty intervention, especially where there is deep-seated distrust of the educational system, is one that also emerges in Muhammad Salisu Abdullahi's chapter on the Almajiri system for educating young males in Nigeria's predominately Hausa-Muslim northern region.

Regardless of the route they take, or where they end up, West African youth who migrate (or emigrate) often find themselves in a double bind: on the one hand, increasingly clandestine and perilous passages expose them to life-threatening risk and exploitation; on the other, restrictive visa 
and immigration policies, anti-Black racism in Global North countries, and xenophobia in South Africa, further curtail their upward mobility. Despite this, as Lanre Ikuteyijo's chapter on youth migration as a survival strategy shows, for certain young Africans, the allure of emigration, especially to Europe and North America, is strong. The responses of the young women and men interviewed in Ikuteyijo's study are in stark contrast to those of the university students interviewed by Dabesaki Mac-Ikemenjima in his chapter on youth aspirations. In his study, which appears in Part II of this book, Mac-Ikemenjima found that across gender university students had minimal interest in migrating away from Nigeria.

Ikuteyijo's research on Nigerian youth who engage in extralegal, "irregular," migration responds to the challenge posed by CanadianNigerian scholars Charles Adeyanju and Temitope Oriola in their 2011 essay on the phenomenology of voluntary African migration to Western countries. Their analysis of "African desideratum for the West" led them to exhort scholars to "pay more theoretical and empirical attention to prospective African immigrants' and migrants' percepts of self and society and their implications for international and transnational migration" (Adeyanju \& Oriola, 2011, p. 945).

Accordingly, using in-depth interviews and focus group discussions with youths in selected Nigerian urban centers who expressed a predisposition toward, or had actual experience with, migration, Ikuteyijo produced qualitative research revealing these youths' own perceptions and understandings of irregular migration, the kinds of survival strategies they adopted in destination countries, and their experiences as returnee migrants. His research shows that many of the youths who migrated irregularly were ignorant of migration law basics (such as the need to hold a passport), and most were not motivated solely by economic reasons. The majority of young people in his sample expressed a desire for social status or, as one of the young men put it, "integrity" at home in Nigeria. Ikuteyijo's findings support Adeyanju's and Oriola's (2011) nuanced tentative conclusion that: "In addition to scarcity of material opportunities, Africans' interests in the West are rooted in three interrelated extraeconomic factors: colonial discourse, migrants' accounts of presentation of self, and the contemporary mass media" (p.961).

Ikuteyijo's chapter also highlights the disconnect between the "garnished front stage" and "concealed back stage" of migrants' lives, that is, between their representations of life abroad to family and peers within their social networks and the actual hardships, including racism, that they face in Europe and North America. Adeyanju and Oriola (2011) suggested that "one of the reasons why non-White migrants traverse their ancestral or 
former and current or host societies to 'show off' is to compensate for their experience of racialization in the latter" (p. 958).

Research questions pertaining to migration and race are also surfaced in the chapter on Black immigrant youth in Newark, New Jersey, coauthored by Mahako Etta and Michael Simmons. Etta and Simmons highlight the need for greater awareness and more in-depth study of emergent educational challenges and opportunities presented by the increasing presence of West African immigrant youth within Newark's school population. The City of Newark is the largest city in the state of New Jersey, and one of the poorest cities in the United States, with a highly diverse, majority Black and Hispanic, population. The city is often seen as an exemplar of a US nationwide trend of lagging educational attainment and increasing economic vulnerability: the rate at which Newark residents obtain any type of postsecondary degree or credential is among the lowest for comparable postindustrial US cities. As Etta and Simmons allude, removing barriers to post secondary attainment is among the key challenges that local youth-serving organizations have set out to tackle (Burd, 2015; Backstrand \& Donaldson, 2018).

The starting point for the study conducted by Etta and Simmons is evidence showing a significant increase in Newark's foreign-born population since 2000. They trace this increase to changes in US immigration laws dating back to the 1960s, and find that immigrants mainly from Ghana and Nigeria account for it. They probe perceptions of Newark schoolteachers, principals, and other adults who are beginning to observe the newly unfolding demographics at one of Newark's largest local public high schools. Their findings reveal that the same youth categorized as "vulnerable" in the West African employment context are also viewed as youth at risk (school dropouts or juvenile delinquents) or "model minorities" (i.e., vis-à-vis native-born Black youth) in the United States.

Etta and Simmons' call for both disaggregated, school-level data, on Newark students' immigrant status to enable a more fine-grained understanding of the city's "Black" student population, and qualitative research examining the social interactions and academic achievement levels of students who are West African-born, also signals a drawback of this book collection's main focus on Anglophone West Africa. Adult volunteers who work with African immigrant youth in the Newark and New York Metropolitan Area report that youth whose families originate from Francophone West African countries are forced to grapple with "intersecting inequalities" compounded by language barriers, as well as other factors, such as low educational levels and underemployment of parents (see also Suárez-Orozco, Yoshikawa, \& Tseng, 2015). They observe that, con- 
trary to the "model minority" stereotype, many Newark Area immigrant youth of Francophone (as well as similarly situated youth of Anglophone) West African origin are at least as vulnerable and "at risk" as many Newark Area Black youth who are native-born Americans (Z. Yamba, A. K. Khalfani, and D. Kassimou, personal communication, March 25, 2017; D. Kassimou, personal communication, July 2, 2019). Together with Etta and Simmons' findings, this observation about the complexities of immigrant-native differences, and constraints on the socioeconomic mobility of Black immigrants in cities like Newark (Bennet \& Lutz, 2009), points further to the range of issues that could be the focus of transatlantic research-practice collaborations.

\section{Agency and Aspirations}

Departing from the developmentalist literature that focuses on at-risk and delinquent behaviors of African youth, the chapters in this section explore how youth in West Africa exert agency and aspire toward the future, often with high expectations, even when facing harsh circumstances. They are resourceful and enterprising in identifying and accessing tools at their disposal (Kabiru, Mojola, Beguy, \& Okigbo, 2013). Additionally, contrary to the global mass media images that portray African youth, especially young African men, as desperate, reckless, and readily inclined to risk life and limb to leave the continent, the youth portrayed in these chapters adjust their expectations to circumstances. All three chapters respond to the call for more research on African youth agency and aspirations and expectations.

Sociologist Charles Payne (2012) observes that the "intellectual development for Black children [in the United States] is ordinarily development under hostile conditions" (p. 6). Despite major gains in recent years, the same assessment applies with respect to the vast majority of children living in Africa. A research study conducted by the Center for Universal Education at Brookings found that, despite increasing access to education in sub-Saharan African countries, rates of extreme education poverty and inequalities between the rich and poor within countries persist (van Fleet, 2012). The researchers concluded that of "Africa's nearly 128 million school-aged children, [some] 37 million African children will learn so little while they are in school that they will not be much better off than [the estimated 17 million] kids who never attend school" (van Fleet, 2012). The authors of the study point to "a deeper learning crisis that needs to be addressed" (van Fleet, 2012). These hostile conditions necessarily weigh 
on the attitudes and aspirations of marginalized Black youth in the multiple (educational, livelihood and employment, family formation, civic participation, etc.) dimensions of their transitions from youth to adulthood.

Yet, as Cecilia Fiaka's first-person testimony attests, even for children and youth living in difficult circumstances, cultural and familial bonds and individual character traits such as tenacity can shield individuals from the harshest consequences of poverty. These kinship, familial, and individual resources provide the basis for meaningful hope and real positive improvement in youths' lives and prospects for satisfying conditions of life in adulthood. Fiaka's experience evokes Afua Twum-Danso Imoh's (2016) critique of the conventional literature and its "overwhelming focus on childhoods [in Africa] defined by what they lack" (p. 456), a tendency which, she argues, has led to "the creation of a false dichotomy between Northern childhoods and the multitude of childhoods that are located in the diverse contexts that exist in the South" (p. 457). Fiaka recounts her personal testimony of growing up in an economically depressed region of rural Ghana in the 1960s. Hers is the compelling story of how she went from being a "house help" to a banker to an activist on behalf of rural youth. Her journey led her to become the founder and director of the award-winning Nneka Foundation, which works in rural communities across Ghana.

Dabesaki Mac-Ikemenjima's chapter on youth aspirations contributes to filling the gap in the literature on the content of youths' goals in subSaharan Africa-a gap in understanding that especially pertains to subgroups of youth like undergraduate students. Mac-Ikemenjima's analysis is based on data from interviews, focus group discussions, and the administration of a questionnaire to undergraduate students in the Niger Delta city of Port Harcourt, Nigeria. Through a grounded theory analysis of the data collected, he identifies an array of youth goals that he ascribes to four categories: material, achievement, generativity, and relationship. Except in one area, both the qualitative and quantitative analyses show consistency across gender, with all respondents showing minimal interest in migrating away from Nigeria. This is in stark contrast to the results of Lanre Ikuteyijo's qualitative study of how (largely unemployed and less educated) youth in five cities in western Nigeria view the prospect of emigration favorably. Additionally, as compared to their male peers, the female undergraduates in Mac-Ikemenjima's study were far more likely to aspire to the goal of marriage, as a path toward economic stability. Other research shows that while, increasingly, marriage does not provide the economic refuge that young women might seek, it does spare them the stigma of 
single womanhood, and sanction their having children, in Nigeria (Ntoimo \& Isiugo-Abanihe, 2014). The research on women suggests that there may be more to the gender disparity in undergraduates' views on marriage than meets the eye. These findings provide nuanced insights, and raise questions for further investigation, pertaining to the disparate perspectives of young people in West Africa facing different challenges and, as MacIkemenjima urges, should prompt more in-depth and comparative research on youth aspirations.

In West Africa, as elsewhere, the process of "being" as well as "becoming" is all the more complex for young people who live with some form of disability. In his chapter, Carsten Mildner examines how three young people who are deaf navigate obstacles as they transition to adulthood. As these three life sketches illustrate, being deaf is not just a medical condition but a social role within both a community of peers and the broader society. Mildner's study portrays the multiple layers of relationship within various settings (family and caregivers, school, within and beyond communities of other deaf people, etc.) and the hurdles that these young people must navigate. Despite, and perhaps because of, their disability, the young people in his study exhibit a high degree of determination and resilience as they at once strive to determine themselves and are being determined.

This chapter provides a compelling glimpse into the largely unexplored frontier of youths living with disabilities in West Africa. It highlights how little is known, and how much there is to learn, about the dynamics-positive as well as negative-of experiencing life, nurturing aspirations, and moving toward adulthood as young persons whose disabilities are part of a multifaceted, intersecting, and shifting set of identities. What are the intricacies of present-day challenges facing young people with disabilities who function in settings where colonization, enslavement, and legalized racial segregation and discrimination are part of the historical legacy? Do such legacies call for further questioning of assumptions about identity, belonging, cultural influence, and definitions of community? What viable educational policy alternatives exist for the majority of Beninese deaf youth who do not know the Francophone West African variant of American Sign Language, whose grasp of French grammar is limited, or who live in rural communities where the predominantly spoken languages are indigenous rather than European? These are some of the questions that lend themselves to comparative investigation. For instance, based upon empirical and qualitative research conducted in South Africa and the United States, 
respectively, South African Sign Language and Black American Sign Language (Black ASL) have both been recognized as coexisting (rather than derivational) forms of signing, each with its own distinctive structure, grammar, and culturally embedded sociality (Reagan, 2008; Sellers, 2012) Researchers formally regard Black ASL as "a rich signing system that reflects both a history of segregation and the ongoing influence of spoken [Black] English" (Sellers, 2012).

Despite the numerous multilayered, day-to-day, and broader challenges they face, each of the young people whom Mildner profiles displays creativity, ingenuity, and grit in envisioning and striving toward possibilities. Together the profiles further challenge the globally applicable, dominant paradigm according to which deafness is essentially a condition of deficiency to be "measured against the hearing norm" (Reagan, 2008 pp. 166-167, 172). Related to this, the profiles also expose the fallacies and pitfalls of the pervasive tendency to view African (and Africandescendant) youth from a deficit rather than asset perspective (see, e.g., Boyd, 2010). The profiles provide evidence of the interplay of individual characteristics, family, school, culture, community, and worldview in contributing to the resilience of youth whose physiology and identity qualities somehow set them apart from a particular mainstream (see, e.g., Boyd, 2010; Williamson, 2007). Youth resilience in the face of disability is another topic area worthy of exploration from a transnational and comparative perspective.

Sally A. Nuamah's chapter on girls' achievement contributes to the body of research showing that achievement-oriented identities, and individual characteristics such as grit, resilience, and confidence, though important, are not sufficient to assure viable pathways to youth success and well-being. Nuamah is a Ghanaian-born scholar-activist based in the United States whose research on the significance of confidence as a variable in girls' achievement challenges conventional views that prevail among researchers concerned about youth outcomes. Nuamah proffers analysis and insights that researchers, practitioners, and others in a variety of national settings - outside as well as within Africa - will find critical for understanding and devising strategies to eliminate gendered barriers to girls' achievement. The choice to compare conditions in Ghana and South Africa, a "lower middle income" and a "middle income country," respectively, is purposeful and illuminating. In Ghana, facially neutral policies (for instance, deferred university enrollment after secondary school completion as a mechanism to manage the acute shortage of capacity to meet 
demand for tertiary education) have a disproportionately negative impact on girls, given the prevalence of forces, e.g. family pressure to marry, inclined to divert girls from educational pathways. In a similar vein, despite its higher national income and distinctively progressive national constitution and progressive laws, South Africa ranks poorly on global indices of gender equality and math and science performance and achievement. Nuamah's analysis shows that a singular focus on increasing confidencethat is, on girls' character traits-is insufficient for closing the girls' achievement gap. Her call for more research that probes the impact of entrenched structural barriers, and measures that bolster individual-level factors, e.g. deeply committed teachers, positive broad community engagement, and other supports, should command the attention of researchers and practitioners concerned with girls' achievement, whether in Ghana, South Africa-or the United States.

\section{Vulnerability and WeLl-Being}

The chapters in Part III explore issues of youth vulnerability on multiple levels, beginning with obstacles that stand in the way of securing a modicum of economic security. For the vast majority of youth in Western Africa, working poverty is the norm (International Labour Organization [ILO], 2016). Studies show that these young people lack educational access and credentials and need multiple income-generating activities in order to survive. Over time, even for those who have the advantage of relatively higher levels of educational attainment, the pervasive lack of access to supported pathways for personal growth and development yields progressively worsening employment prospects and a permanent wage gap in lifetime earnings (ILO, 2015, 2016; UNICEF, 2014). This scarring effect is felt worldwide by youth from low-income families around the world, including Black youth in the diaspora.

In their regression analysis of youth vulnerability in Ghana's labor markets, researchers Adedeji Adeniran, Joseph Ishaku, and Adekunle Yusuf highlight the prospect of long-term scarring that looms large in the work lives of the vast majority of youth in West Africa. Here again the variability of how youth is defined is underscored: life expectancy in Ghana is pegged at age 64 , and, therefore, in this study, the time spans between "youth" (people between the ages of 15 and 24), "middle age," and "old age" are relatively small. The study undertaken by Adeniran et al. probes wellestablished research findings and theory that conclude that gender, educa- 
tion, and location are major determinants of labor market vulnerability. They show that the probability of vulnerability increases for youth who are female, who lack formal education, and who reside in rural areas. But the main contribution of the study is the evidence it provides of how vulnerability appears to taper off during "middle age," the age range from 25 to 54 , but then resumes at age 55 . This evidence of the connection between vulnerability during youth and prospects for later life will help to inform and shape policy interventions that target youth but not in isolation from other age cohorts.

The vulnerability of the young people that Muhammad Salisu Abdullahi writes about takes the form of joblessness and material insecurity, created and compounded by historical and cultural forces. The Almajiri system of traditional Qur'anic "boarding schools" that exists throughout northern Nigeria is used mainly by poor rural families who lack other educational alternatives. Abdullahi, who is an entrepreneur trained in biochemistry, cites social anthropologist Hanna Hoechner, who traces the history of the Almajiri system's decline beginning during the era of British colonial rule. As the introduction of "modern education" by the British undermined the control of literacy by northern Nigerian religious scholars, the system went from being a reliable and prestigious avenue for enrolled children and youth (known as Almajirai or Almajiranci) to transition to successful adulthood, to an entrenched coping strategy for the extreme poor. Unable to afford the modern Islamic education available to members of the middle class, and distrustful of the poor quality of the secular schools that are accessible to them-and with good reason-poor peasant households persist in demanding Almajiri.

Like the parents of out-of-school immigrants who are the focus of Daniel Kyereko's study in Part I, the parents of Almajirai are distrustful of the modern model of formal schooling, which has become "firmly established within development discourse and practice as the development intervention par excellence [and] one of the defining features of modern childhood" (Hoechner, 2011, p. 712). An estimated 9.5 million-plus children and youth are enrolled in Almajiri Qur'anic schools across Nigeria, most in the northern part of the country where Abdullahi's enterprise is based (Creative Associates International, 2015; Hoechner, 2011).

Abdullahi contrasts his experience of growing up in a middle-class Hausa-Muslim family with the struggles he witnessed of Almajirai friends in his neighborhood, which inspired him to direct his training and entrepreneurial talent toward devising a positive intervention. Whereas much, 
if not most, of the policy literature focuses on these youth as a security challenge, if at all, this chapter sheds light on the religious and historical roots of the practice-including its positive elements, such as its contribution to community cohesion and role in introducing literacy. It also shows how young West Africans like Abdullahi are not oblivious to the impact of structural inequality and, although seldom credited in press reports emanating from of the West (Europe and the United States), are in the vanguard of social entrepreneurial efforts to improve poor peoples' lives in West Africa. Among many, including influential business leaders and philanthropists and politicians in the United States, there is a growing realization that education access is not a panacea, and school reform is not an adequate substitute for inadequate household incomes (Hanauer, 2019; Strauss, 2019). Viewed in this wider context, Abdullahi's chapter suggests the possibility of transnational comparative investigation of not only the efficacy of social entrepreneur-led interventions, but also policies to provide guaranteed basic incomes, efforts to promote distributive justice, and other approaches to easing financial pressures on families and expanding meaningful educational opportunities for children and youth-in the United States and in African countries.

In the final chapter, Kenneth Juma, Frederick Murunga Wekesah, Caroline W. Kabiru, and Chimaraoke O. Izugbara, a Pan-African group of public health specialists based in Kenya and the United States, take up the issue of poor mental health among youth in West and Central Africa, from a public health services perspective. They begin by contextualizing the many challenges that cut across these regions-for instance, the acute lack of data and documentation, and the large numbers of diagnosed youth who go untreated-by observing that the prevalence of youth mental and substance use disorders as well as the treatment gap are global issues.

This observation is borne out by research focused on the United States. A 2016 study found that more than a third of children across the United States had experienced childhood trauma "such as the death or incarceration of a parent, witnessing or being a victim of violence, or living with someone who has been suicidal or had a drug or alcohol problem," which increased the likelihood of "[derailed] healthy physical, social, emotional, and cognitive development" (Robert Wood Johnson Foundation, 2017). In the state of New Jersey alone, the rate of exposure to adverse childhood experiences was reportedly $41 \%$ for children under the age of 17 (NJ Partnership for Healthy Kids, 2018). Moreover, in the United States "evidence consistently suggests that, across the life course, mental disorder 
prevalence varies significantly according to race and ethnicity" (Alegría, Green, McLaughlin, \& Loder, 2015, p. 15), with issues such as lack of treatment impacting Black and other youth of color disproportionately. Indeed research shows that even high economic status does not inoculate Black American youth from the debilitating mental health effects of longterm exposure to systemic racism (Assari, Gibbons, \& Simons, 2018).

Notwithstanding enormous regional differences in the availability of data, documentation, and analysis, resources of all kinds, and levels of awareness, this chapter suggests topics for collaborative and comparative research. In their review of the literature, the coauthors "found gendered differences in the epidemiology of poor mental health, with adolescent girls in West and Central Africa being more vulnerable to depression than boys." This contrasts with research in the United States possibly showing a greater susceptibility to depression among Black boys of color who suffer exposure to trauma and violence (Rich, 2016). Suggesting a possible area of congruence, also worth examining, the chapter cites research suggesting the efficacy of school, community, and culture-based mental health interventions, for instance in Nigeria, Liberia, and Sierra Leone. In his historical overview of the introduction of Western psychiatry in the colonial era, and its practice in the postcolonial period, in Africa, historian Emmanuel Akyeampong notes that "in Africa a precedent was set for community care in mental health before this direction became evident in the West" (Akyeampong, 2015, p. 27). Given shared concerns about the impact of exposure to trauma, lack of information compounded by stigma and cultural beliefs, and the ubiquitous lack of capacity to meet the demand for treatment, researchers and practitioners concerned about gaining a handle on mental and substance abuse disorders among young people in Africa and Black diaspora communities could usefully examine and compare and contrast the efficacy of community- and culture-based mental health care approaches across national and continental borders.

Unfolding national, local, and global permutations of inequality are prompting practitioners, activists, and scholars-including those among the contributing authors to this collection-to hold the challenges facing youth in Africa and in the diaspora "in simultaneous view." These more unconventional ways of framing and approaching youth-related challenges depart from thinking solely about "places of poverty" (Roy, 2015). They 
move toward border-transcending analytical frameworks and problemsolving approaches that are more likely to increase understanding of the nature of African and African diaspora youth challenges and better suited to designing opportunity pathways for them. This book aspires toward the vision of both focusing in on and transcending space as a way of gaining a more fine-grained understanding of the challenges of African and Africandescendant youth, exploring opportunity pathways, and providing additional rungs for moving further in that direction.

\section{REFERENCES}

Adeyanju, C. T., \& Oriola, T. B. (2011). Colonialism and contemporary African migration: A phenomenological approach. Journal of Black Studies, $42(6), 943-967$.

Akyeampong, E. (2015). A historical overview of psychiatry in Africa. In E. Kyeampong, A. G. Hil, \& A. M. Kleinman (Eds.), The culture of mental illness and psychiatric practice in Africa (pp. 24-49). Bloomington: Indiana University Press.

Alegría, M., Green, J. G., McLaughlin, K. A., \& Loder, S. (2015). Disparities in child and adolescent mental health and mental health services in the U.S. Retrieved June 12, 2019, from https://wtgrantfoundation.org/library/ uploads /2015/09/Disparities-in-Child-and-Adolescent-Mental-Health.pdf

Amemasor, J. A. (2002). Opening the door of return. The International Journal of Narrative Therapy and Community Work: African American Perspectives, Healing Past \& Present (2), 60-63.

Assari, S., Gibbons, F. X., \& Simons, R. (2018). Depression among black youth; Interaction of class and place. Brain Sciences, 8(6), 108. https://doi. org/10.3390/brainsci8060108. Retrieved June 3, 2019, from https://www. ncbi.nlm.nih.gov/pmc/articles/PMC6025590/

Backstrand, J. R., \& Donaldson, K. (2018). Post-secondary outcomes of Newark High School Graduates (2011-2016). Newark, NJ: Newark City of Learning Collaborative, Rutgers University-Newark Joseph C. Cornwall Center for Metropolitan Studies. Retrieved September 12, 2018, from https://nclc2025. org/wp-content/uploads/2018/09/UPDATE-2018-Post-SecondaryOutcomes-Report.pdf

BBC News Africa. (2018, December 15). Opal Tometi: How Nigeria helped inspire \#BlackLivesMatter [video]. Retrieved March 29, 2019, from https://www. youtube.com/watch?v=PrcGMozDdSY

Bennet, P. R., \& Lutz, A. (2009). How African American is the net black advantage? Differences in college attendance among immigrant blacks, native blacks, and whites. Sociology of Education, 82(1), 70-100. 
Black Alliance for Just Immigration (BAJI). (n.d.). Who we are. Retrieved March 29, 2019, from https://baji.org/who-we-are/

Black Lives Matter. (n.d.). Herstory. Retrieved March 29, 2019, from https:// blacklivesmatter.com/about/herstory/

Boyd, A. C. (2010). The trials and triumphs of Black deaf students. The Journal of Deaf Studies and Deaf Education, 15(2), 204.

Bronstein, S., Lyon, A., \& Poolos, A. (2010, December 3). Held as slaves, now free. CNN. Retrieved May 10, 2019, from http://www.cnn.com/2010/ CRIME/12/02/slave.labor.ring.busted/index.html

Burd, S. (2015, July 1). One struggling city's bold effort to increase its number of college graduates. The Hechinger Report. Retrieved December 5, 2018, from https://hechingerreport.org/one-struggling-citys-bold-effort-to-increaseits-number-of-college-graduates /

Charrière, F., \& Frésia, M. (2008). West Africa as a migration and protection area. New York, NY: United Nations High Commissioner for Refugees. Retrieved May 3, 2016, from http://www.unhcr.org/49e479c311.pdf

Comaroff, J., \& Comaroff, J. (2005). Reflections on youth from the past to the postcolony. In A. M. Honwana \& F. De Boeck (Eds.), Makers \& breakers: Children \& youth in postcolonial Africa (pp. 19-30). Oxford, UK: James Currey.

Creative Associates International. (2015). Integrated Qur'anic education: Nigeria case study. Washington, DC: Author. Retrieved March 29, 2019, from https:// www.creativeassociatesinternational.com/wp-content/uploads/2003/01/ Integrated_Ed-Nigeria.pdf

Durham, D. (2000). Youth and the social imagination in Africa: Introduction to parts 1 and 2. Anthropological Quarterly, 73(3), 113-120.

Flanders, L. (2015, August 5). Opal Tometi on building a transnational movement for Black lives. Truthout. Retrieved March 29, 2019, from https:// truthout.org/articles/opal-tometi-on-building-a-transnational-movementfor-black-lives /

Hanauer, N. (2019, July). Better schools won't fix America. The Atlantic. Retrieved June 20, 2019, from https://www.theatlantic.com/magazine/ archive/2019/07/education-isnt-enough/590611/

Hardgrove, A., Pells, K., Boyden, J., \& Dornan, P. (2014). Youth vulnerabilities in life course transitions. New York, NY: United Nations Development Programme, Human Development Report Office. Retrieved December 5, 2018, from http://hdr.undp.org/sites/default/files/hardgrove_boyden_hdr_2014.pdf

Hoechner, H. (2011). Striving for knowledge and dignity: How Qur'anic students in Kano, Nigeria, learn to live with rejection and educational disadvantage. European Journal of Development Research, 23(5), 712-728.

Honwana, A. (2014). 'Waithood.' Youth transitions and social change. In D. Foeken, T. Dietz, L. De Haan, \& L. Johnson (Eds.), Development and 
equity. An interdisciplinary exploration by ten scholars from Africa, Asia and Latin America (pp. 28-40). Leiden, Netherlands: Brill.

Honwana, A., \& De Boeck, F. (2005). Children \& youth in Africa, agency, identity, \& place. In A. M. Honwana \& F. De Boeck (Eds.), Makers \& breakers: Children \& youth in postcolonial Africa (pp. 1-18). Oxford, UK: James Currey.

International Labour Organization. (2015). Global employment trends for youth 2015: Scaling up investments in decent jobs for youth. Geneva, Switzerland: International Labour Office.

International Labour Organization. (2016). World employment social outlook: Trends for youth 2016. Geneva, Switzerland: International Labour Office. Retrieved May 31, 2016, from https://www.ilo.org/wcmsp5/groups/ public/\%2D\%2D-dgreports/\%2D\%2D-dcomm/\%2D $\% 2 \mathrm{D}$-publ/documents/ publication/wcms_513739.pdf

Kabiru, C. W., Mojola, S. A., Beguy, D., \& Okigbo, C. (2013). Growing up at the 'margins': Concerns, aspirations, and expectations of young people living in Nairobi's slums. Journal of Research on Adolescence, 23(1), 81-94.

Katz, M. B. (2013). The undeserving poor: America's enduring confrontation with poverty. New York: Oxford University Press.

Mberu, B. U., \& Pongou, R. (2010). Nigeria: Multiple forms of mobility in Africa's demographic giant. Migration Information Source. Retrieved March 29, 2019, from https://www.migrationpolicy.org/article/ nigeria-multiple-forms-mobility-africas-demographic-giant

Mills, C. W. (1997). The racial contract. Ithaca, NY: Cornell University Press.

Nelson, A. (2016). The longue durée of Black Lives Matter. American Journal of Public Health, 106(10), 1734-1737.

New Jersey Historical Commission. (2019). New Jersey Historical Commission, fiscal year 2019 grant awards. Retrieved July 3, 2019, from https://www.nj.gov/ state/historical/assets/pdf/fy2019-grants-all.pdf

NJ Partnership for Healthy Kids. (2018, January 16). Adverse childhood experiences among biggest issue facing children. Retrieved June 12, 2019, from https://www.njhealthykids.org/adverse-childhood-experiences-among-biggestissue-facing-children/

Ntoimo, L. F. C., \& Isiugo-Abanihe, U. (2014). Patriarchy and singlehood among women in Lagos, Nigeria. Journal of Family Issues, 35(14), 1980-2008. https://doi.org/10.1177/0192513X13511249

O'Connor, A. (2001). Poverty knowledge: Social science, social policy, and the poor in twentieth-century U.S. history. Princeton, NJ: Princeton University Press.

Payne, C. (2012). Countering the master narratives: The 'why?' of education for liberation. Voices in Urban Education, 34(Summer), 6-14. Retrieved May, 22, 2017, from http://www.annenberginstitute.org/sites/default/files/VUE34. pdf 
Philipps, J. (2014). Dealing with diversity: African youth research and the potential of comparative approaches. Journal of Youth Studies, 17(10), 1362-1377.

Philipps, P. (2018). A global generation? Youth studies in a postcolonial world. Societies, $8(1), 1-18$.

Ransby, B. (2018). Making all Black lives matter: Reimagining freedom in the twenty-first century. Oakland: University of California Press.

Reagan, T. (2008). South African Sign Language and language-in-education policy in South Africa. Stellenbosch Papers in Linguistics, 38, 165-190.

Rich, J. (2016). Moving toward healing: Trauma and violence and boys and young men of color. Retrieved July 9, 2019, from https://media.wix.com/ugd/ fb2077_b4d750a1479a4072972e774db167db5f.pdf

Robert Wood Johnson Foundation. (2017, October 19). Traumatic experiences widespread among U.S. youth, New data show. Retrieved June 12, 2019, from https://www.rwjf.org/en/library/articles-and-news/2017/10/traumaticexperiences-widespread-among-u-s\%2D\%2Dyouth $\% 2 \mathrm{D} \% 2 \mathrm{Dnew}$-datashow.html

Roy, A. (2015). Introduction: The aporias of poverty. In A. Roy \& E. S. Crane (Eds.), Territories of poverty: Rethinking north and south (pp. 1-35). Athens: University of Georgia Press.

Rutgers University-Newark. (2014). Where opportunity meets excellence. Strategic plan 2014. Retrieved May 25, 2016, from http://www.newark.rutgers.edu/ sites/default/files/run_strategic_plan_-final.pdf

Rutgers University-Newark. (2018, May 14). Queen Latifah receives honorary doctorate at commencement 2018. Retrieved May 14, 2018, from https://www. newark.rutgers.edu/news/rutgers-university-newark-announces-queen-latifahcommencement-speaker-and-honorary-degree

Salomon, S. H. (2010, December 5). African girls held as slaves in New Jersey. The Root. Retrieved May 10, 2019, from https://www.theroot.com/ african-girls-held-as-slaves-in-new-jersey-1790881860

Sellers, F. S. (2012, September 17). Sign language that African Americans use is different from that of whites. The Washington Post. Retrieved July 7, 2019, from https://www.washingtonpost.com/lifestyle/style/sign-language-thatafrican-americans-use-is-different-from-that-of-whites /2012/09/17/2e897628bbe2-11el-8867-ecf6cb7935ef_story.html?noredirect=on \&utm_term = . ed448a0ad35b

Strauss, V. (2019, June 19). A mega-wealthy philanthropist changes his mind about school reform and what kids really need-and Barack Obama has a surprising reaction. The Washington Post. Retrieved June 20, 2019, from https:// www.washingtonpost.com/education/2019/06/19/billionaire-changes-his-mindabout-school-reform-what-kids-really-need-barack-obama-has-surprisingreaction/?utm_term $=.75 \mathrm{db} 8 \mathrm{bb} 34 \mathrm{c} 25$ 
Strong, K. (2018). Do African lives matter to Black Lives Matter? Youth uprisings and the borders of solidarity. Urban Education, 53(2), 265-285.

Suárez-Orozco, C., Yoshikawa, H. \& Tseng, V. (2015). Intersecting inequalities: Research to reduce inequality for immigrant-origin children and youth. Retrieved July 24, 2018, from http://wtgrantfoundation.org/library/uploads/2015/ 09/Intersecting-Inequalities-Research-to-Reduce-Inequality-for-ImmigrantOrigin-Children-and-Youth.pdf

Tometi, O. (2015, April 30). What Pew's new report didn't tell you about Black immigrants. Huffington Post. Retrieved March 29, 2019, from https://www. huffingtonpost.com/opal-tometi/what-the-pews-new-report-didnt-tell-youabout-black-immigrants_b_7174070.html

Twum-Danso Imoh, A. (2016). From the singular to the plural: Exploring diversities in contemporary childhoods in sub-Saharan Africa. Childhood, $23(3), 455-468$.

United Nations International Children's Emergency Fund (UNICEF) (2014). Generation 2030 Africa 2.0. Prioritizing investments in children to reap the demographic dividend. Retrieved March 29, 2019, from https://data.unicef. org/wp-content/uploads/2017/11/Generation_2030_Africa_2.0.pdf

van Fleet, J. (2012, September 17). Africa's education crisis: In school but not learning. Brookings. Retrieved June 12, 2019, from https://www.brookings. edu/blog/up-front/2012/09/17/africas-education-crisis-in-school-but-notlearning/

Williamson, C. (2007). Black deaf students: A model for educational success. Washington, DC: Gallaudet University Press.

Yahya, M. (2017, August 7). Africa's defining challenge [Blog post]. United Nations Development Programme. Retrieved August 11, 2017, from http:// www.africa.undp.org/content/rba/en/home/blog/2017/8/7/africa_defining_challenge.html 
Open Access This chapter is licensed under the terms of the Creative Commons Attribution 4.0 International License (http://creativecommons.org/licenses/ by $/ 4.0 /$ ), which permits use, sharing, adaptation, distribution and reproduction in any medium or format, as long as you give appropriate credit to the original author(s) and the source, provide a link to the Creative Commons licence and indicate if changes were made.

The images or other third party material in this chapter are included in the chapter's Creative Commons licence, unless indicated otherwise in a credit line to the material. If material is not included in the chapter's Creative Commons licence and your intended use is not permitted by statutory regulation or exceeds the permitted use, you will need to obtain permission directly from the copyright holder.

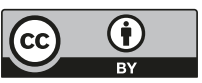

